\title{
Reoperacje w przebiegu otitis media chronica cholesteatomatosa
}

\author{
Reoperations in patients with chronic otitis media cholesteatomatosa \\ Maciej Wiatr, Karolina Hydzik-Sobocińska, Agnieszka Morawska, Jacek Składzień, \\ Jerzy Tomik, Robert Przeklasa, Krzysztof Oleś, Adam Miodoński
}

\section{SUMMARY}

Introduction: Chronic cholesteatoma otitis media, apart from destruction of bones and possibility of otogenous complications, is characterized by possibility of recurrence of the disease after non radical treatment or presence of risk factors.

Aim: This paper intends to analyze changes typical for cholesteatoma, observed during otosurgery including the results of bacteriological investigations. Material and methods: Nearly 450 otosurgeries were performed in Department of Otolaryngology at Jagiellonian University 2004-2007. Analysis refers to patients reoperated on chronic cholesteatoma otitis media.

Results: 47 reoperations in the course of chronic choleateatoma otitis media were performed. Bacteriological analysis was provided in 21 cases. The most common bacteria were Stahylococcus aureus and Pseudomonas aeruginosa. Biofilms were not observed in specimens.

Conclusions: The recurrence of the process should be expected in patients with cholesteatoma. They require regular, periodical follow-up examination. Hasła indeksowe: przewlekłe zapalenie ucha środkowego, perlak, reoperacje ucha Key words: chronic otitis media cholesteatoma, ears' reoperations

\author{
Cby Polskie Towarzystwo Otorynolaryngologów \\ - Chirurgów Głowy i Szyi \\ Otrzymano/Received: \\ 16.05 .2010 \\ Zaakceptowano do druku/Accepted: \\ 30.06.2010 \\ Katedra i Klinika Otolaryngologii \\ Uniwersytet Jagielloński Collegium Medicum \\ Kierownik: Prof. dr hab. Jacek Skladzień \\ Wklad pracy autorów/Authors contribution: \\ Maciej Wiatr - główny badacz, \\ Jacek Składzień, Adam Miodoński - nadzór nad \\ badaniami i interpretacja wyników, \\ Jerzy Tomik, Robert Przeklasa, Krzysztof Oleś, \\ Karolina Hydzik-Sobocińska, Agnieszka Morawaka \\ - gromadzenie i analiza zebranych danych \\ Konflikt interesu/Conflicts of interest. \\ Autorzy pracy nie zgłaszają konfliktu interesów. \\ Adres do korespondencji/ \\ Address for correspondence: \\ imię i nazwisko: Maciej Wiatr \\ adres pocztowy: \\ Katedra i Klinika Otolaryngologii, Uniwersytet \\ Jagielloński \\ Collegium Medicum \\ ul. Śniadeckich 2 \\ 31-531 kraków \\ tel. $(+12)$ 424-79-00 \\ fax $(+12)$ 424-79-2 \\ e-mail mwiatr@mp.pl
}

Otolaryngol Pol 2010; 64 (5): $313-317$

\section{Wstęp}

Skutecznym i jedynym sposobem leczenia przewlekłych zmian zapalnych ucha środkowego jest zabieg operacyjny. Celem chirurgii ucha środkowego jest całkowite usunięcie nieprawidłowych tkanek i następnie rekonstrukcja układu kosteczek słuchowych. Największe zniszczenia prawidłowych struktur kostnych ucha środkowego obserwuje się $\mathrm{w}$ przebiegu przewlekłego perlakowego oraz przewlekłego ziarninowego zapalenia ucha środkowego (Ryc. 1).

Niejednokrotnie poza uszkodzeniem układu przewodzącego dźwięk dochodzi do ubytkôw ścian kostnych ucha środkowego, co otwiera drogę do rozwoju powikłań wewnątrzskroniowych, a także wewnątrzczaszkowych. Nieradykalne usunięcie zmian chorobowych czy brak właściwej wentylacji przestrzeni ucha środkowego prowadzą do nawrotu procesu chorobowego w uchu środkowym [1-3].

\section{Materiał i metoda}

W latach 2004-2007 w Klinice Otolaryngologii CMUJ w Krakowic operacje uszne wykonano u 450 chorych. Operowano: 232 kobiety i 218 mężczyzn. Najstarszy chory miał 78 lat, najmłodszy 6 lat. Średnia wieku wynosiła 36 lat. Z powodu przewlekłego zapalenia ucha środkowego operowano 319 chorych.

Do niniejszej pracy rozpatrywano chorych reoperowanych $\mathrm{z}$ powodu wznowy procesu perlakowego w przestrzeniach ucha środkowego. Analizowana grupa obejmowała 47 chorych. Zabieg przeprowadzono u 24 kobiet i 23 mężczyzn. Najmłodszy chory miał 8 lat, najstarszy 78 lat. Srednia wieku wynosiła 37 lat. $\mathrm{Z}$ badania wyłączono chorych, u których wykonano operacje second look.

Przeprowadzono prospektywną analizę pacjentów leczonych z powodu schorzeń ucha środkowego w Klinice Otolaryngologii Collegium Medicum Uniwersytetu Jagiellonskiego. Zestawiając przedstawiony materiał, rozpatrywano dane uzyskane $\mathrm{z}$ dokumentacji medycznej leczonych chorych, $\mathrm{tj}$.: kart ambulatoryjnych, historii chorób, a takíe $z$ odległych kontroli pooperacyjnych. W opracowaniu oparto się na kwestionariuszu zawierającym pytania opisujące badaną grupę, postępowanie diagnostyczne wobec pacjenta, metodyke operacyjną i rezultaty badań ostrości słuchu.

W analizie uwzględniono wyniki badania bakteriologicznego wydzieliny z ucha środkowego. Oceniano 


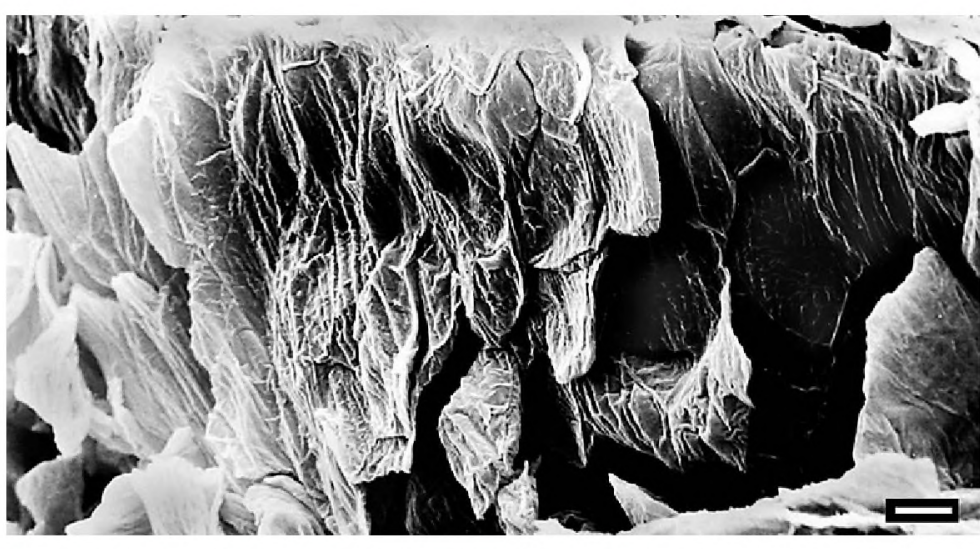

Ryc. 1. Perlak w elektronowym mikroskopie skaningowym

Fig. 1. The cholesteatoma in scanning electron microscopy

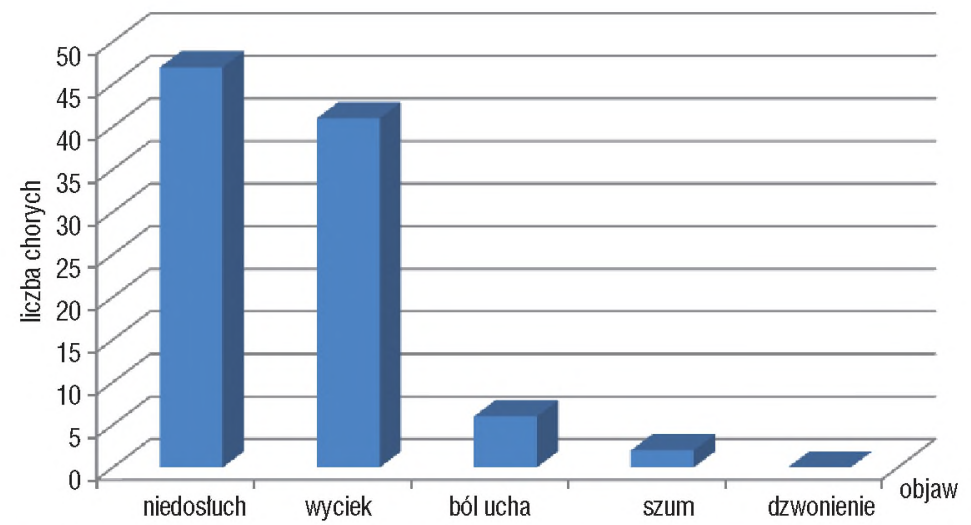

Ryc. 2. Dolegliwości zglaszane przez chorych w okresie przedoperacyjnym

Fig. 2. Symptoms in preoperative period

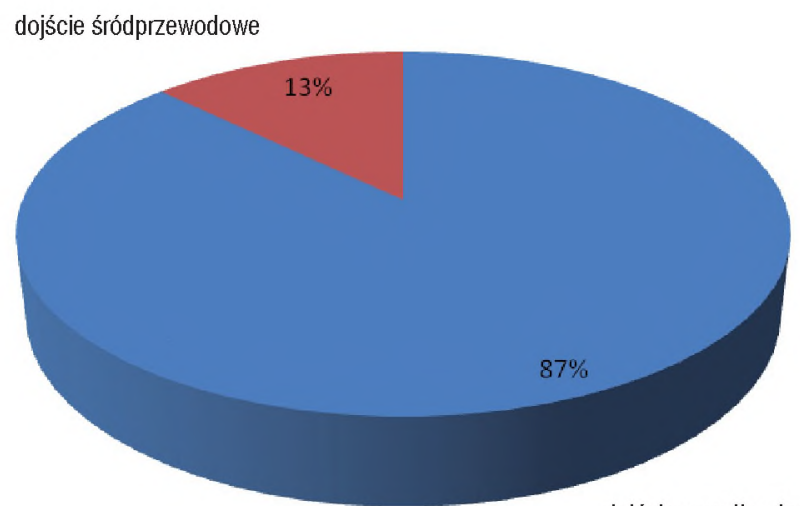

dojście zamałzowinowe

Ryc. 3. Rodzaj dostępu do ucha środkowego

Fig. 3. Approaches to middle ear spaces

wydzielinę pobraną w okresie bezpośrednio przedoperacyjnym. W razie wątpliwości pobierano materiał do oceny ewentualnego biofilmu.

\section{Wyniki}

W analizowanym okresie operacje uszne wykonano u 450 chorych. $Z$ powodu nawrotu perlaka ucha środkowego leczono 47 chorych. Stanowi to blisko $40 \%$ wykonanych reoperacji ucha środkowego w omawianym przedziale czasu. Średnia wieku reoperowanych wynosiła 37 lat.

Okres, który upłynął od poprzedniego zabiegu na uchu środkowym, wynosił od 4 miesięcy do blisko 15 lat. Większość chorych była reoperowana w czasie dłuższym niż 2 lata od wcześniejszej operacji ucha środkowego. $\mathrm{W}$ analizowanym materiale reoperacja $\mathrm{w}$ równym stopniu dotyczyła ucha prawego (23) i lewego (24).

Objawem wspólnym zgłaszanym przez wszystkich chorych był niedosłuch. Większość chorych (87\%) zgłaszała w wywiadzie przedoperacyjnym wyciek $z$ ucha. Na ból ucha skarżył się co dziesiąty reoperowany. Szum stwierdzono $\mathrm{u} 2$ chorych, nikt nie zgłaszał dzwonienia w uchu (Ryc. 2).

U większości chorych stosowano dojście zauszne. Dostęp śródprzewodowy wybrano tylko u 6 chorych (Ryc. 3).

Najczęściej proces perlakowy był zaawansowany i u blisko połowy chorych obejmował wszystkie przestrzenie ucha środkowego. U 1/3 operowanych zmiany chorobowe lokalizowały się w zachyłku attykowym $z$ zajęciem przestrzeni wyrostka sutkowatego. Najrzadziej perlak w sposób izolowany występował w zachyłku attykowym (4 chorych) (Ryc. 4).

U $32 \%$ pacjentôw perlakowi nie towarzyszyły inne nieprawidłowości wyściółki ucha środkowego. U $22 \%$ operowanych poza perlakiem stwierdzono zmiany przerostowe błony śluzowej, z porównywalną częstością obecne były także jednoczasowo przerost błony śluzowej i ziarnina. Zrosty obserwowano u 3 operowanych (Ryc. 5).

$\mathrm{Z}$ uwagi na znaczne zaawansowanie procesu perlakowego u większości chorych konieczne było szerokie uwidocznienie i oczyszczenie przestrzeni ucha środkowego. U 85\% pacjentów wykonano atticoantromastoidectomię, znosząc również tylno-górną ścianę przewodu słuchowego zewnętrznego, u 3 chorych wykonano atticotomię. Zabieg był ograniczony do jamy bębenkowej u 2 chorych (Ryc. 6).

$Z$ uwagi na zaawansowanie procesu perlakowego u 5 chorych nie rekonstruowano łańcucha kosteczek słuchowych, wykonując operację radykalną, ale bez obliteracji ujścia trąbki słuchowej Eustachiusza. Z drugiej strony u zaledwie 3 chorych, przy niewielkim nasileniu procesu chorobowego, łańcuch kosteczek pozostawał nienaruszony. Najczęściej uszkodzenie łańcucha kosteczek było duże, a u 38\% reoperowanych dotyczyło także suprastruktury strzemiączka. „Małe ucho” $z$ odtworzeniem błony bębenkowej w poziomie kanału nerwu twarzowego wy tworzono łacznie u $65 \%$ chorych. W pojedynczych przypadkach wykonano tympanoplastykę typu II. W tych przypadkach rekonstruując układ przewodzacy ucha środkowego, wykorzystywano 
domodelowaną własna kosteczkę chorego lub rurkę wentylacyjną umieszczoną na głôwce strzemiączka (Ryc. 7).

U 9 chorych wyrostek sutkowaty obliterowano uszypułowanym płatem mięśniowym.

Tympanoplastykę typu otwartego wykonano u większości chorych (85\% operowanych). Tylno-górną ścianę przewodu słuchowego zewnętrznego zaoszczędzano, gdy istniała całkowita pewność usunięcia zmian chorobowych. Dotyczyło to głôwnie chorych $z$ perlakiem ogra niczonym do jamy bębenkowej i przy braku wątpliwości co do drożności ujścia trąbki słuchowej.

W 20\% obserwowano śródoperacyjnie ubytek ściany kostnej podstawy czaszki. U 7 chorych w zakresie ściany kostnej środkowego dołu czaszki, a u 2 dalszych pacjentôw tylnego dołu czaszki. U jednego chorego obecna była przepuklina oponowo-mózgowa w zakresie środkowego dołu czaszki.

U 2 chorych obserwowano ubytek siciany kostnej kanału nerwu twarzowego, a 13 przetokę na kanale półkolistym poziomym. Z obecnością przetoki korelowały zgłaszane $\mathrm{w}$ wywiadzie przedoperacyjnym zawroty głowy.

Badanie bakteriologiczne wykonano u blisko połowy operowanych chorych, u których identyfikowano wyciek z jamy pooperacyjnej. Diagnostykę tę prowadzono w przypadku czynnego wycieku $z$ ucha w okresie przedoperacyjnym. Następnie chorzy poddawani byli celowanej antybiotykoterapii miejscowej, a w nasilonych przypadkach także ogólnej, tak aby uzyskać „suche ucho" i umożliwić przeprowadzenie zabiegu operacyjnego. Najczęściej w wymazach obserwowano Stahylococcus aureus oraz Pseudomonas aeruginosa (Ryc. 8).

Opierając się na uzyskanych wynikach badania bakteriologicznego, $u$ większości chorych stosowano ciprofloxacinę należącą do grupy fluorochinolonów.

Oporność na stosowaną antybiotykoterapię jest obserwowana w terapii zarówno ostrych, jak i przewlekłych infekcji górnych dróg oddechowych. Spowodowane jest to często obecnością biofilmu bakteryjnego, który interferując $z$ zastosowanym antybiotykiem, powoduje, $\mathrm{i} \dot{z}$ jedynym skutecznym postępowaniem terapeutycznym staje się leczenie chirurgiczne. U analizowanych reoperowanych chorych nie stwierdzono biofilmów.

\section{Omówienie}

Jedynym sprawdzonym i skutecznym sposobem leczenia przewlekłych zmian zapalnych ucha środkowego jest postępowanie operacyjne. Aktualnie obowiązujące standardy zakładają w pierwszym rzędzie usunięcie nieprawidłowych tkanek, a następnie podjęcie rekonstrukcji aparatu przewodzącego dźwięk w jamie bębenkowej.

Proces perlakowy charakteryzuje się stale postępująca destrukcja struktur kostnych ucha środkowego. W przebiegu tego schorzenia zawsze należy liczyć się z możliwością nawrotu dolegliwości. Pacjenci wymagają

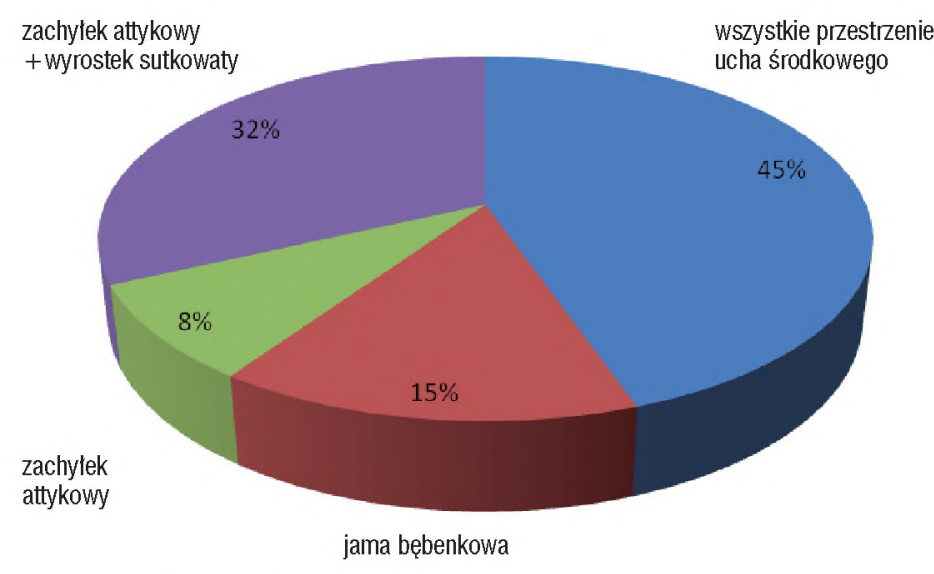

Ryc. 4. Lokalizacja perlaka

Fig. 4. Location of cholesteatoma

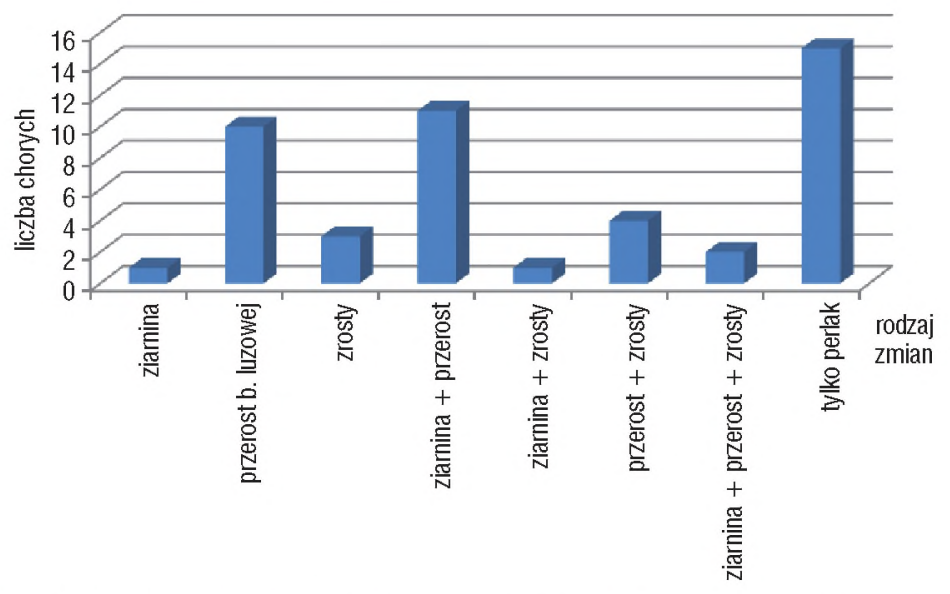

Ryc. 5. Nieprawidłowości wyściółki ucha środkowego towarzyszące zmianom perlakowym

Fig. 5. Changes to middle ear mucous in patients with cholesteatoma

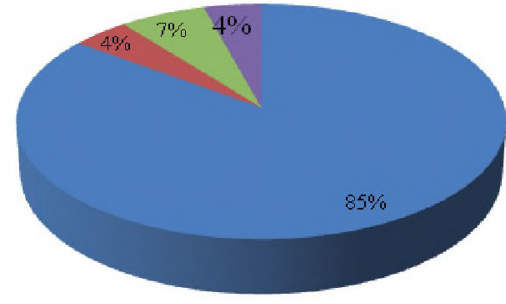

- atticoantromastoidectomia

- tympanomia tylna

atticotomia

zabieg ograniczony

do jamy bębenkowej

Ryc. 6. Zakres zabiegu operacyjnego w obrębie kości skroniowej

Fig. 6. Range of surgery in temporal bone

regularnych, okresowych kontroli laryngologicznych z wykonaniem operacji second look włącznie [4, 5].

Szeroki zakres czasu, w jakim po pierwotnym leczeniu operacyjnym obserwowano wznowę procesu perlakowego, podkreśla wagę kontroli, a także właściwego postępowania pooperacyjnego zmierzające- 

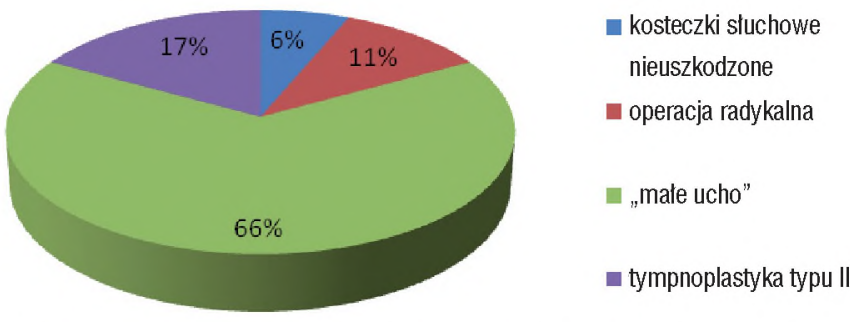

Ryc. 7. Sposoby rekonstrukcji łańcucha kosteczek słuchowych

Fig. 7. Ways of ossicular chain reconstruction

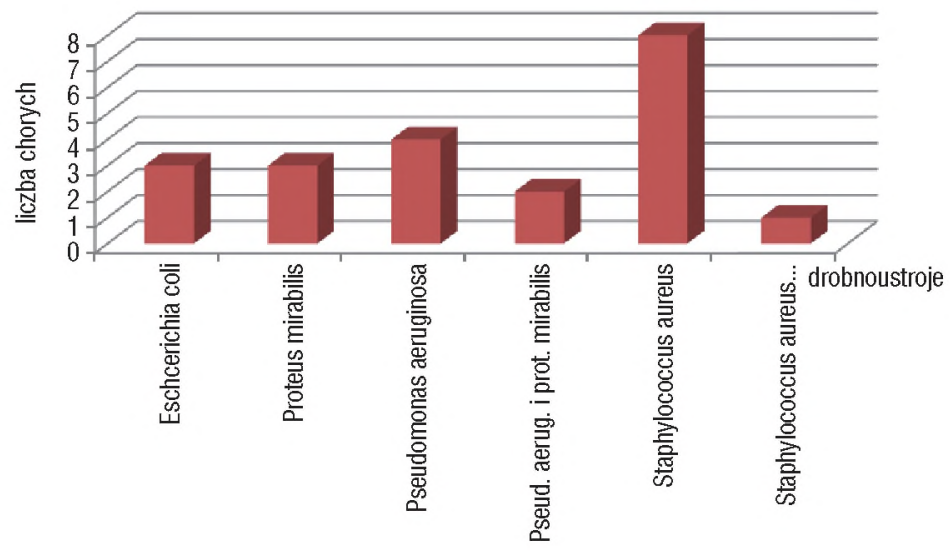

Ryc. 8. Wyniki badania bakteriologicznego wydzieliny z ucha środkowego

Fig. 8. Results of bacteriological examination of material from middle ear

go do zapewnienia należytej toalety oraz wentylacji przestrzeni ucha środkowego. W metodyce operacyjnej preferowano dostęp zauszny stwarzający możliwość szerszego wglądu w proces toczący się $\mathrm{w}$ przestrzeniach pneumatycznych wyrostka sutkowatego.

Obserwowana rozległość zmian chorobowych determinowała szerokie otwarcie przestrzeni ucha środkowego i jednocześnie ograniczała możliwości rekonstrukcyjne. U większości chorych, przy prawidłowej funkcji trąbki słuchowej, błonę bębenkową odtwarzano w poziomie kanału nerwu twarzowego tworząc "małe ucho". Wiązało się to $z$ tympanoplastyką typu otwartego. Zniesienie tylno-górnej ściany przewodu słuchowego zewnętrznego zapewnia dobry wgląd w jamę wyrostka sutkowatego, umożliwiając jego oczyszczanie i ewentualne wczesne wykrycie nawrotu dolegliwości [6, 7, 8]. Tympanoplastykę zamkniętą wykonano tylko w kilku przy padkach, u młodych chorych, gdy proces chorobowy był ograniczony do jamy bębenkowej i usunięcie perlaka było pewne [9, 10].

Wobec nawrotu schorzenia, jego rozległości i w świetle zagrażających powikłań usznopochodnych nadrzęd ne znaczenie $\mathrm{w}$ analizowanej grupie miało radykalne usunięcie procesu chorobowego. Przy takim założeniu obserwowana poprawa słuchu po przeprowadzonej ope racji ucha oraz przy znacznym uszkodzeniu kosteczek słuchowych niejednokrotnie była niewielka [11, 12].

W analizowanej grupie często obserwowano brak 1. i 2. kosteczki słuchowej, czemu u znacznego odsetka operowanych towarzyszył brak suprastruktury strzemiączka. Zachowanie nienaruszonej 3. kosteczki słuchowej ma kardynalne znaczenie dla następowej rekonstrukcji układu przewodzącego dźwięk i związanej z tym poprawy słuchu.

Na uwagę zasługuje dwukrotnie większa niż u chorych operowanych po raz pierwszy częstość ubytków kości podstawy czaszki. Można to tłumaczyć większym zaawansowaniem procesu chorobowego u tych chorych. Odsłonięcie opony twardej tylnego dołu czaszki obserwowano 4-krotnie rzadziej niż w obrębie dołu środkowego (u operowanych po raz pierwszy 10 razy rzadziej w zakresie tylnego niż środkowego dołu czaszki) [13, 14].

Częstość uby tków kanału kostnego nerwu VII czy przetoki na kanale półkolistym poziomym nie odbiegała od obserwacji u chorych, którzy byli operowanych po raz pierwszy (obserwacje własne autorôw).

\section{Wnioski}

1. Reoperacja w przebiegu przewlekłego perlakowego zapalenia ucha środkowego wymaga dobrego wgladu i szerokiego otwarcia przestrzeni ucha środkowego.

2. Chorzy po usunięciu perlaka wymagają wieloletnich kontroli celem wykrycia ewentualnej wznowy procesu chorobowego.

3. Częstość ubytkôw kości podstawy czaszki jest dwukrotnie większa w grupie chorych reoperowanych w stosunku do operowanych po raz pierwszy.

4. Znaczne uszkodzenie kosteczek słuchowych często nie pozwala na skuteczną rekonstrukcję aparatu przewodzącego dźwięk w uchu środkowym.

5. W przypadku reoperacji w przebiegu przewlekłego perlakowego zapalenia ucha środkowego preferuje się tympanoplastykę typu otwartego.

6. U reoperowanych w przebiegu przewlekłego zapalenia ucha środkowego istotnie częściej obserwuje się uby tki kości podstawy tylnego dołu czaszki, niż u operowanych po raz pierwszy.

\section{P I ŚM I E N N I C T W O}

1. Vartiainen E, Vartiainen J. Hearing results of surgery for acquired cholesteatoma. Ear Nose Throat J 1995; 74(3): $160-2,164$.

2. Wiatr M, Składzień J, Tomik J. Przewlekłe zapalenie ucha środkowego jako wstęp do usznopochodnych powikłań wewnątrzczaszkowych. Otolaryngol Pol 2008; 1: 49-53.

3. Khan I, Jan AM, Shahzad F: Middle-ear reconstruction: a review of 150 cases. J Laryngol Otol 2002; 116(6): 435-9.

4. Ayache S, Tramier B, Strunski V. Otoendoscopy in cholesteatoma surgery of the middle ear: what benefits can be expected? Otol Neurotol 2008; 29(8): 1085-90. 
5. Babighian G. Posterior and attic wall osteoplasty: hearing results and recurrence rates in cholesteatoma. Otol Neurotol 2002; 23(1): 14-7.

6. McElveen JT Jr, Chung AT, Reversible canal wall down mastoidectomy for acquired cholesteatomas: preliminary results. Laryngoscope.2003; 113(6): 1027-33.

7. Ikeda M, Yoshida S, Ikui A i wsp. Canal wall down tym panoplasty with canal reconstruction for middle-ear cholesteatoma: post-operative hearing, cholesteatoma recurrence, and status of re-aeration of reconstructed middle-ear cavity. J Laryngol Otol 2003; 117(4): 249-55.

8. Jeng FC, Tsai MH,Brown CJ. Relationship of preoperative findings and ossicular discontinuity in chronic otitis media. Otol. Neurotol 2003; 24(1): 29-32.

9. Mills R. Cholesteatoma behind an intact tympanic membrane in adult life: congenital or acquired? J Laryn gol Otol 2009; 4: 1-4.
10. Dodson EE, Hashisaki GT, Hobgood TC i wsp. Intact canal wall mastoidectomywith tympanoplasty for cholesteatoma in children. Laryngoscope 1998; 108(7): 977-83.

11. Kos MI, Castrillon R, Montandon P. Anatomic and functional long-term results of canal wall-down mastoidectomy. Ann Otol Rhinol Laryngol 2004; 113(11): 872-6.

12. Nomura $\mathrm{K}$, Iino $\mathrm{Y}$, Hashimoto $\mathrm{H}$ i wsp. Hearing results after tympanoplastyin elderly patients with middle ear cholesteatoma. Acta Otolaryngol 2001; 121(8): 919-24.

13. Hildmann H, Sudhoff H.Cholesteatoma in children. Int J Pediatr Otorhinolaryngol 1999; 5(49), Suppl 1: 81-6.

14. Guaranta N, Fernandez-Vega Feijoo S, Piazza F. Closed tympanoplastyin cholesteatoma surgery: long-term (10 years) hearing results using cartilage ossiculoplasty. Eur Arch Otorhinolaryngol 2001; 258(1): $20-4$. 